\section{S NEWS and VIEWS}

Geology at Birmingham :

Prof. L. J. Wills

Prof. L. J. WILLS retires from the chair of geology in the Univerginy of Birmingham at the end of this session. Prof. Wils, like his predecessors, has shown that he is narrow spegialist, and one has only to look at a listof his paper or read his books to realize this. He[has througlout Joen a stratigrapher in the widest Adnse, and when carrying out detailed palæpntdogical work has always had in view the fod that the plants or animals he is describing were ofcelliting organisms making up part of the environmest in which they lived. His early work on the flora and faunas of the Bromsgrove Trias gave a picture of a desert oasis with its inhabitants of scorpions living among the cycads; later his work on the Geological Survey took him on to the North Welsh Lower Palæozoic rocks of the Llangollen syncline, an area excellent for the teaching of young students, and many generations of Birmingham undergraduates have benefited from visits under his guidance to this district. Another line of research which Prof. Wills has followed deals with the history of the Dee and Severn Rivers, and in this he has elucidated the history of these rivers and their relationship to the glacial episodes of the West Midlands and North Wales. Perhaps his most striking pieces of work, however, are his two books, "The Physiographic Evolution of Britain" and the "Palæogeography of the Midlands". These epitomize his teaching of stratigraphy and have influenced teaching not only in Birmingham but also in all the universities throughout Great Britain. His many friends and former students will wish him many years of happy and fruitful retirement, for, like so many geologists, he shows no sign of growing old.<smiles>C1C[C@H]2CC[C@H](C1)C2</smiles>

Prof. F. W. Shotton

Prof. F. W. Shotron, of the University of Sheffield, who succeeds Prof. Wills, is a native of Coventry and was educated at Bablake School, gaining an open scholarship to Sidney Sussex College, Cambridge. After gopduating, ho spent a year on research at Cambridge. During $1928-36$ he was a lecturer in geology in thp Un versity of Birmingham, returning to Calnofidge in the latter year as a lecturer. He sezed in the for from 1940 to 1945 , being geological ofncer to H.Q Middle East during 1941-43, and later he served with the Twenty-First Army Group in Normandy and Belgium. After the War he was appointed professor of geology in the University of Sheffield (see Nature, 155, 664; 1945).

\section{East Malling Research Station: Dr. F. R. Tubbs}

DR. F. R. TuBBs, who has been appointed director of the East Malling Research Station in succession to Sir Ronald Hgtton, took up his new duties on July 1. Dr. Tubbs, tho is forty-one, studied at the Imperial College of Science and Technology. After graduating, he was/awarded a Ministry of Agriculture postgraduate scholarship in plant physiology. For work on the ffect of manurial deficiency upon the mechanical strength of barley straw, carried out under the direction of Dr. F. G. Gregory at Rothamsted, he was awarded the degree of M.Sc. After spending six months at the East Malling and Long Ashton Research Stations, he proceeded to Ceylon in 1930 to found a Department of Plant Physiology at the Tea Research Institute of Ceylon. In 1935 he was awarded the degree of Ph.D. in the University of London for a thesis on the influence of climate and type of pruning on the growth of tea. He also studied methods of vegetative propagation, selection, etc., of the tea bush. After serving in the Army from 1939, he was placed on the retired list in December 1945 with the rank of lieut.-colonel, and returned to Ceylon to resume his investigations at the Tea Research Institute. He returned to Britain in 1948 to take up an appointment as manager in charge of the Horticultural Division of the Food Research Organisation of Messrs. Lever Bros. and Unilever, Ltd., at Sharnbrook, Bedfordshire.

Statistics in the University of London:

Dr. M. G. Kendall

Dr. M. G. KENDaLl has been appointed to a newly created of statistics in the University of London and will take up his appointment in October at the London School of Economics. Dr. Kendall gaduat in mathematjics at Cambridge (Wrangler, Q92 and entere of $k 5$ administrative class of the Ci. Sertice in ${ }_{30}$. He became head of the E\&om mics Intef ifence Branch of the Ministry of Agriculture if 938 , resigning in 1941 to accept the post of statistlelan at the Chamber of Shipping. He became joint assistant general manager at the Chamber in 1946. Dr. Kendall's interests have been largely in mathematical statistics, on which he has written numerous papers; but he has also published work on the applications of statistics to problems of agriculture, shipping, etc. $\mathrm{He}$ has written the standard text-book on the "Advanced Theory of Statistics". Dr. Kendall has also published "Tables of Random Sampling Numbers" (with B. Babington Smith, 1939), "Contributions to the Study of Oscillatory Time-Series" (1946) and "Rank Correlation Methods" (1948). He has been very active in the Royal Statistical Society, in which he has held various offices; the Society awarded him its Silver Medal in 1946. Among the more recent of Dr. Kendall's distinctions have been his election to the International Statistical Institute in 1948, and the award this year of the degree of Sc.D. of the University of Cambridge.

Water-Supply and Rainfall over the British Isles

A statement hofbeen issued by the UnderSecretary of State for Air relating to the recent shortage of cainfdll over the British Isles and its effect upon heldountry's water-supply. In it attention is direct to warnings given by water engineers that gvor much of England there is likely to be a shortagt of water during the next few months, and thif is followed by some statistics of recent rainfall, and some notes on the meteorological aspects of the situation. It is pointed out that the threat of shortage of supply is greatest for south-east England, where reliance is placed mainly on deep-seated water supply; that deep water sources there are dependent for replenishment upon winter rainfall being at least up to the average. Much of the summer fall is lost by evaporation or taken up by vegetation, so that little or none percolates to great depths ; moreover, most of south-east England had less than 70 per cent of its average rainfall during the period October 1948 to March 1949. The winter was not only dry, but also very mild. After the eight winters in the last fifty years that have been both mild and dry, the succeeding spring and summer were dry as often as they were wet, therefore no expectation of a return 
to normal conditions can be based on the character of the past winter. Another discouraging feature is that the deficiency of rainfall is equally well marked over a large part of Europe. The immediate cause of the deficiency is the abnormal frequency and persistence of anticyclones over the area affected, combined with a displacement northwards of the tracks of the eastward-moving depressions with their attendant rain; but in the absence of any clue to the cause of these abnormal features of the general circulation of the atmosphere, their duration cannot be predicted.

\section{Sky Survey by the Schmidy Telescope at Palomar}

A PROJECT of photograshing the heavens has been announced by tod Aational Geographic Society, Washington, 1 which is sponsoring the scheme, and by the Mt. Filson-Palomar Observatories, which will carry but the programme, and will be known as the Natiohal Geographic Society-Palomar Observa ory Sky Survey. The main work will be done by the 1 -in. Schmidt telescope on Mt. Palomar, and the fies photographs will be taken on July 19, weather permitting, on which night a ceremony will be held in the Schmidt dome. It is expected that the work will be completed in 1953, when three-quarters of the sky out to an average distance of 300 million lightyears will have been photographed. Unusual phenomena recorded by the Schmidt telescope will be studied more intensively later by the "pin-pointing instrument of maximum penetration"-the 200-in. giant at Palomar. Virtually identical exposures of each area will be made by using both blue and red filters to permit comparisons of the widely different pictures obtained in the different colours. When completed, the Survey will record about 500 million stars and perhaps 10 million extra-galactic nebulæ. The "Sky Atlas" which includes this survey will be the equivalent of about twenty large volumes, and it is hoped that the Atlas can be produced at a cost of 2,000 dollars a copy. These will be supplied at cost price to observatories, astronomers, and higher educational institutions throughout the world "to advance the cause of human knowledge". The relatively low cost of production is due to the generous financial assistance rendered by the National Geographic Society. This Survey will prove invaluable as a research guide for the great observatories and will also be an immense boon for the smaller observatories, and for astronomers engaged in theoretical studies, who will be able to use the Survey photographs without recourse to their own telescopic observations. It is believed that the results will be an astronomical bible for at least a century to come.

\section{American Geologists for British Colonial Develop- ment}

REFERENCE was made in Nature of May 28 to the proposed recruitment of American geologists for service in various British Colonial geological surveys. It is statg in Economic Geology of May that the Economif Co-operation Administration has undertaken to finance in part the employment of about twent -five geologists, petrographers and chemistassafers for this purpose. The men will be employed by/the U.S. Geological Survey, and it is proposed to rocruit seventeen field geologists, two petrologists, two chemist-assayers and four ground-water geologists. The qualifications suggested are an honours degree in geology with five years professional field experience, and it is hoped that a few men of longer experience will also be attracted. They will be placed in grades 6-8 of the U.S. Geological Survey according to qualifications, so that their salaries will range from about 8,000 dollars a year upwards. The fields in which they will be employed are given as Nigeria, Gold Coast, Sierra Leone, Kenya, Tanganyika, Uganda, Nyasaland, North Borneo and Sarawak, and British Guiana. Recruitment is to be for three years, after which it is expected that British-trained geologists will be available. The measure is intended to be a temporary expedient devised to overcome lack of personnel in the Colonial geological surveys attributed to the interruption of training during the War.

\section{Uganda Society}

ReCEnTLy in these glumns, accounts have been given of the formation of philosophical societies in two British Colonios in Africa. In Uganda there exists such a body which is well established, both in terms of yeays and activity of membership. The Uganda Soglety, a non-racial, cultural and scientific society, yas reborn in its present form in. 1933 through the inspration of Mr. E. J. Wayland, then director of tho Geological Survey, and Mr. (now Sir) Ralph Hone, then attorney-general in Uganda. Its transactions are published in the Uganda Journal (Oxford University Press) and include a range of subjects embracing ethnology, archæology, geology and local history. The Society has sponsored two major publications, namely: "A Guide to the Snakes of Uganda", by Captain C. R. S. Pitman ; and "Uganda Memories", by Sir Albert Cook. Other books are in course of publication. The present membership of this Society, which it is hoped to increase further, is now more than seven hundred. The officers for 1949 are: President, Dr. Goronwy ap Griffith; VicePresident, Rev. Father F. B. Gaffiney; Editor, Mr. W. V. Harris ; Librarian, Mrs. Barbara Saben; Hon. Secretary, Mr. J. Addington; Hon. Treasurer, Mr. C. W. Stuart. The address of the Society is P.O. Private Bag, Kampala, Uganda.

\section{Education in Industry: Topics for Research}

$$
516
$$

IN an interesting fiticle in Further Education (3, No. 1 ; June Aygust, 1949), Dr. P. Dunsheath, the chairman of British Association for Education in Industhy and Commerce, discusses some of the probleres wlidh have arisen as the result of the growth of dication in industry. When considering the range of dbility, outlook and intelligence among individuals, Dr. Dunsheath indicates that considerable research should be done on the basis of selection for technical courses. Then, remembering that the people affected by education and training in industry are of all ages and positions, he suggests that the problem of how far industrial organisation should concern itself with educational facilities for employees already well established should also be resolved.

Among other questions raised by the author are the following. Should the practical training of engineering students precede a full-time course at a university or technical college, or should it follow the academic course on entry into industrial employment, or should periods of practical work be interposed during the academic years in the form of vacation or sandwich courses? Is it right for a young man destined to become a draughtsman or a designer to spend years at the bench becoming a skilled fitter? Can education be planned for cooperation? To what extent can arts graduates compete with science graduates for the senior posts in industry ? Is management within the next decade 